\title{
Vegetative propagation of lemon balm on different substrates
}

\author{
Propagação vegetativa de erva-cidreira em diferentes substratos
}

\begin{abstract}
Rafael Santiago da Costa ${ }^{1}$; Letícia Kenia Bessa de Oliveiraa ${ }^{1}$ Ingrid Kethyane Beserra Holanda ${ }^{1}$; Maria de Fátima Barbosa Coelho²; Aiala Vieira Amorim ${ }^{3^{*}}$

${ }^{1}$ Estudantes de Agronomia, Universidade da Integração Internacional da Lusofonia Afro-Brasileira (Unilab), Instituto de Desenvolvimento Rural (IDR), rafaelsantiagodacosta@yahoo.com.br, leticia.kbo7@gmail.com; ingridholanda10@gmail.com ${ }^{2}$ Professora Doutora, Universidade Federal de Mato Grosso (UFMT), coelhomfstrela@gmail.com

${ }^{3}$ Corresponding author. Professora Doutora, Universidade da Integração Internacional da Lusofonia Afro-Brasileira (Unilab), Instituto de Desenvolvimento Rural (IDR), Campus da Liberdade, Av. da Abolição, 3 - Centro, Redenção, CEP: 62.790-000, Ceará, Brasil, aialaamorim@unilab.edu.br
\end{abstract}

Recebido em: 25-01-2017; Aceito em: 09-05-2017

\begin{abstract}
The production of seedlings by cutting is influenced by several factors, among them the type of substrate. In this context, the objective of this work was to evaluate the effect of different substrates on the vegetative propagation of lemon balm (Lippia alba). The experiment was carried out during the period from August to October 2014, in the municipality of Redenção, Ceará. The experimental design was in randomized blocks, with five treatments: $\mathrm{T} 1$ = soil, T2 = soil + bovine manure (2:1, v:v), T3 = soil + earthworm humus (2:1, v:v), T4 = soil + plant organic matter (2:1, v:v), T5 = soil + bovine manure + earthworm humus + plant organic matter (2:1:1:1, v:v:v:v) and five replicates. Apical herbaceous branches were used to produce the cuttings, with the cutting being done in polystyrene trays. After a period of 35 days, the cuttings were removed from the trays and the number of leaves and shoots, length of root and shoot, fresh and dry mass of the cuttings were evaluated. The data obtained were submitted to analysis of variance and, subsequently, when significant by $F$ test, to the Scott-Knott test at $5 \%$ probability for comparison of means. It was observed that all the evaluated variables had a significant influence of the types of substrates used, with emphasis on treatments soil + bovine manure + earthworm humus + plant organic matter and soil + bovine manure, in which the cuttings showed better responses. Since these substrates are efficient, they are indicated for the production of $L$. alba seedlings by cutting.
\end{abstract}

Additional keywords: cutting; humus; Lippia alba; medicinal plants; organic matter.

\begin{abstract}
Resumo
A produção de mudas por estaquia é influenciada por vários fatores, dentre eles, o tipo de substrato. Neste contexto, objetivou-se com o presente trabalho avaliar o efeito de diferentes substratos na propagação vegetativa da erva-cidreira (Lippia alba). O experimento foi realizado durante o período de agosto a outubro de 2014, no Município de Redenção, Ceará. $\mathrm{O}$ delineamento experimental foi em blocos casualizados com cinco tratamentos: $\mathrm{T} 1$ = solo, $\mathrm{T} 2$ = solo + esterco bovino (2:1, v:v), T3 = solo + húmus de minhoca $(2: 1, \mathrm{v}: \mathrm{v}), \mathrm{T} 4$ = solo + matéria orgânica vegetal (2:1, v:v), T5 = solo + esterco bovino + húmus de minhoca + matéria orgânica vegetal (2:1:1:1, v:v:v:v) e cinco repetições. Utilizaram-se ramos herbáceos apicais para a produção das estacas, sendo a estaquia realizada em bandejas de poliestireno. Após um período de 35 dias, as estacas foram removidas das bandejas e avaliou-se o número de folhas, de brotações, comprimento da raiz e dos brotos, massa fresca e seca das estacas. Os dados adquiridos foram submetidos à análise de variância e, posteriormente, quando significativa pelo teste F, as médias foram comparadas por meio do teste de Scott-Knott a $5 \%$ de probabilidade. Observou-se que todas as variáveis avaliadas sofreram influência significativa dos tipos de substratos utilizados, com destaque para os tratamentos solo + esterco de bovino + húmus de minhoca + matéria orgânica vegetal e solo + esterco de bovino, nos quais as estacas apresentaram melhores respostas. Por serem substratos eficientes, são indicados para produção de mudas de $L$. alba por estaquia.
\end{abstract}

Palavras-chave adicionais: estaquia; húmus; Lippia alba; matéria orgânica; plantas medicinais.

\section{Introduction}

The use of medicines based on plant species is a practice that accompanies the human being since the dawn of civilization, being based on the accumulation of information passed through successive generations. In Brazil, the use of medicinal plants was dis- seminated by the indigenous culture associated with the traditions of the European settlers (Freire, 2004; Aguiar et al., 2008). Currently, the use of these plants by farmers is common in the manufacture of homemade teas.

Among the medicinal plants commonly used by family farmers, the Brazilian lemon balm [Lippia 
alba (Mill.) N. E. Br.] stands out, belonging to the family Verbenaceae, native to South America and almost all Brazilian territory. It is a sub-shrub species that reaches up to two meters high (Hennebelle et al., 2008; Garcés et al., 2010; Silva et al., 2015), being widely used in Brazil due to its calmative, analgesic, sedative, slightly expectorant, antifungal, insecticidal and repellent properties (Aguiar et al., 2008; Yamamoto et al., 2008).

The propagation of native medicinal plants via seeds has proved to be inadequate for most species, due to the great genetic variability, the time required to reach maturity and problems related to seed viability and dormancy. In addition, vegetative reproduction has been considered a viable alternative for the production of medicinal plant seedlings, allowing plant uniformity, low cost and reduced time, with cutting being the most widespread method (Aguiar et al., 2008; Silva et al., 2015).

Cutting is a form of vegetative propagation that consists of the development of a new plant forming apical buds and adventitious roots, providing the production of clones (Pinto \& Franco, 2009). This method has the advantage of guaranteeing the selection of superior genotypes, in addition to the greater production of seedlings in a shorter period of time (Neves et al., 2006; Coelho et al., 2016).

The production of seedlings by cutting is influenced by several factors, among them the type and time of harvest of the cuttings, as well as the type of substrate used for rooting and its physical and chemical characteristics, which directly influence the survival and rooting of cuttings (Lacerda et al., 2006; Furlan et al., 2007; Silva et al., 2015).

In general, the ideal substrate for cutting must have good water retention capacity, optimum volume of porous spaces filled with gases, easy acquisition availability, essential nutrients, adequate texture and structure, absence of pathogens and economic viability (Lacerda et al., 2006; Furlan et al., 2007; Melo et al., 2008).

The development of efficient alternative substrates for the production of seedlings from local resources allows the recycling of by-products, reducing farming costs and the dependence on non-renewable resources. Thus, organic matter, bovine manure and earthworm humus appear as important components in the formulation of organic substrates, because when mixed with the soil, they contribute with physical and chemical attributes, improving the structure, increasing the porosity and providing the necessary nutrients to seedling development (Lacerda et al., 2006; Costa et al., 2008; Silva et al., 2012).

Although lemon balm is a plant widely used in Brazil, there is little information about its propagation for commercial production. Studies and researches to obtain new information on the lemon balm, seeking to generate knowledge about the substrates suitable for the propagation of this species (Lacerda et al., 2006; Silva et al., 2015), can contribute to broaden its com- mercial use. In this context, the objective of this work was to evaluate the effect of different types of substrates on the vegetative propagation of lemon balm.

\section{Material and methods}

The experiment was conducted during the period from August to October 2014 at the University of International Integration of the Afro-Brazilian Lusophony (UNILAB), Liberdade Campus, located in the Municipality of Redenção, Ceará, at a latitude of

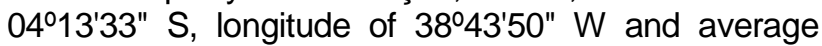
altitude around 88 meters. According to Köppen (1923), the climate of the site is classified as Aw', that is, tropical rainy, very hot.

The experimental design was in randomized blocks, with five treatments and five replicates each, totaling 25 plants per treatment. The treatments used were: $\mathrm{T} 1$ = soil (control treatment), T2 = soil + bovine manure $(2: 1, \mathrm{v}: \mathrm{v}), \mathrm{T} 3$ = soil + earthworm humus $(2: 1$, v:v), T4 = soil + plant organic matter $(2: 1, \mathrm{v}: \mathrm{v}), \mathrm{T} 5=$ soil + bovine manure + earthworm humus + plant organic matter (2:1:1:1, v:v:v:v).

Bovine manure (obtained while still moist) was disposed as a pile and placed for tanning during a 30-day period. The pile was wetted daily and twisted every two days. On the other hand, the organic matter was obtained through the composting of residues from sugarcane (bagasse and leaves) and foliage of ornamental plants, following the same format used for manure, but in a 40-day period and with the temperature being checked daily. As for earthworm humus, this was obtained through vegetable remains in a 30-day period.

Soil, bovine manure, plant organic matter and earthworm humus were obtained at the UNILAB experimental farm, being properly sieved in a 2-mm mesh, mixed and arranged in multicell polystyrene trays. After that, the cuttings were allocated (one per cell) according to the treatments. The soil used in the substrate mixture was an Argisol, typical of the Maciço de Baturité region. The substrates used were sent for laboratory chemical analysis using DTPA/CaCl 2 solution 1:5 (v:v), according to work by Alt \& Peters (1993). The results obtained are available in Table 1.

Lemon balm cuttings (identified botanically by Britton \& Wilson), obtained from apical herbaceous branches of adult plants, were used in August 2014. Bevel (transverse) cuts were performed at the lower end of each cutting, leaving them with approximately $15 \mathrm{~cm}$ in length. Two nodes per cutting were used as a reference for the determination of this length, and then all the leaves were removed.

For the choice of matrices, criteria related to plant health and vigor were used in order to obtain healthy cuttings for propagation. After the cuttings were obtained, they were arranged randomly in the trays filled with substrates. The species exsicata is deposited in the Prisco Bezerra Herbarium of the Federal University of Ceará, under voucher number EAC 588775. 
Table 1 - Chemical attributes of substrates used in the vegetative multiplication of Lippia alba by apical cuttings.

\begin{tabular}{|c|c|c|c|c|c|c|c|c|c|c|c|}
\hline *TTe & C & M.O. & $\mathrm{P}$ & $\mathrm{K}$ & $\mathrm{H}+\mathrm{Al}^{3+}$ & $\mathrm{Na}^{+}$ & $\mathrm{Ca}^{2+}$ & $\mathrm{Mg}^{2+}$ & $\mathrm{Ca}^{2+}+\mathrm{Mg}^{2+}$ & SB & CTC \\
\hline & $--(g$ & $\left.y^{-1}\right)-$ & $\left(\mathrm{mg} \mathrm{dm}^{-3}\right.$ & $\left(\mathrm{cmol}_{\mathrm{c}} \mathrm{dm}^{-3}\right)$ & $--(m g$ & $\left.n^{-3}\right)$--- & & & $-\left(\mathrm{cmol}_{\mathrm{c}} \mathrm{dm}^{-3}\right)-$ & & \\
\hline T1 & 1.88 & 2.9 & 26 & 194 & 0.24 & 96 & 0.4 & 2.1 & 2.5 & 98.74 & 98.98 \\
\hline T2 & 2.60 & 4.1 & 240 & 1646 & 0.00 & 459 & 2.9 & 4.3 & 7.2 & 466.2 & 466.2 \\
\hline T3 & 3.40 & 7.7 & 365 & 376 & 1.22 & 168 & 9.8 & 3.2 & 13 & 182.22 & 183.44 \\
\hline T4 & 4.87 & 8.6 & 74 & 364 & 1.62 & 115 & 9.7 & 7.4 & 17.1 & 133.72 & 135.34 \\
\hline T5 & 4.92 & 8.7 & 338 & 392 & 0.00 & 154 & 9.5 & 7.5 & 17.0 & 171.00 & 171.00 \\
\hline
\end{tabular}

* Treatments: T1 = soil (reference treatment), T2 = soil + cattle manure (2:1, v:v), T3 = soil + earthworm humus,(2:1, v:v), $\mathrm{T} 4$ = soil + plant organic matter $(2: 1, \mathrm{v}: \mathrm{v})$, and T5 = soil + cattle manure + earthworm humus + plant organic matter $(2: 1: 1: 1$, v:v:v:v).

After arranging the cuttings in the trays, these were placed in the open air. Water application was carried out twice a day, one application in the morning and the other in the afternoon, observing the humidity state of the substrate, being made the addition of the same volume of water in each tray.

At 35 days after planting (35 DAP), the cuttings were removed from the trays and subsequently the following variables were evaluated: number of leaves, shoot length, root length, fresh mass of cuttings, dry mass of cuttings and number of shoots; for the latter, weekly shoot counts were performed. For the determination of the variables shoot length and root length, a grid graded in $\mathrm{cm}$ was used, while for weighing the fresh mass and dry mass of the cuttings, a precision scale was used. In order to obtain the dry masses of the cuttings, they were separated, put in suitable containers for this purpose and placed in an oven with forced air circulation at $75^{\circ} \mathrm{C}$ until constant mass.

The data were submitted to a normality test, and analysis of variance (ANOVA) was performed. Subsequently, when significant by $\mathrm{F}$ test, the data were submitted to the Scott-Knott test at 5\% probability, for comparison of means. For statistical analysis, the computational program "ASSISTAT 7.7 BETA" was used.

\section{Results and discussion}

In the summary of the analysis of variance shown in Table 2, it can be observed that all variables analyzed were influenced by the treatments, significant at $1 \%$ probability by the $\mathrm{F}$ test.

Table 2 - Summary of variance analysis for number of leaves (NL), number of shoots (NS), shoot length (SL), root length (RL), fresh mass (FM), and dry mass (DM) of cuttings of Lippia alba grown in different substrates.

\begin{tabular}{lccccccc}
\hline \multirow{2}{*}{ Causes of variation } & \multirow{2}{*}{${ }^{(1)} \mathrm{DF}$} & \multicolumn{7}{c}{ Mean square } \\
\cline { 3 - 8 } & & $\mathrm{NL}$ & $\mathrm{NS}$ & $\mathrm{SL}$ & $\mathrm{RL}$ & $\mathrm{FM}$ & $\mathrm{DM}$ \\
\hline Blocks & 4 & $1.30^{\text {ns }}$ & $2.56^{\text {ns }}$ & $0.30^{\text {ns }}$ & $0.24^{\text {ns }}$ & $106.25^{\text {ns }}$ & $5.01^{\text {ns }}$ \\
Treatments & 4 & $36.30^{\star *}$ & $18.86^{\star *}$ & $7.21^{\star *}$ & $14.00^{\star *}$ & $939.21^{* *}$ & $46.50^{* *}$ \\
Residue & 16 & 1.35 & 1.03 & 0.19 & 0.14 & 112.78 & 9.64 \\
\hline (2)CV $(\%)$ & - & 7.50 & 15.70 & 10.90 & 6.20 & 9.10 & 8.70 \\
\hline
\end{tabular}

(1) Degrees of Freedon; ${ }^{(2)}$ Coefficient of variation; ${ }^{* *}$ Significant by the $\mathrm{F}$ test at $1 \%$ probability; ${ }^{\text {ns }}$ - Not significant.

The same happened to the summary of the means, where all variables were directly influenced by the types of substrates, at $5 \%$ probability by the Scott- Knott test (Table 3). These results resemble those found by Amaro et al. (2013), who, when studying Mentha arvensis, observed that the types of substrates used in the propagation of this plant had a significant influence on all analyzed variables.

Table 3 - Mean values for number of leaves (NL), number of shoots (NS), shoot length (SL), root length (RL), fresh mass (FM) and dry mass (DM) of cuttings of Lippia alba grown in different substrates.

\begin{tabular}{lcccccc}
\hline${ }^{*}$ Treatments & NL & NS & SL $(\mathrm{cm})$ & RL $(\mathrm{cm})$ & FM $(\mathrm{g})$ & DM $(\mathrm{g})$ \\
\hline T1 & $12.82 \mathrm{~d}$ & $4.00 \mathrm{c}$ & $2.66 \mathrm{~d}$ & $4.36 \mathrm{c}$ & $104.85 \mathrm{~b}$ & $32.70 \mathrm{~b}$ \\
T2 & $17.43 \mathrm{~b}$ & $6.80 \mathrm{~b}$ & $5.90 \mathrm{a}$ & $7.98 \mathrm{a}$ & $139.14 \mathrm{a}$ & $40.25 \mathrm{a}$ \\
T3 & $15.21 \mathrm{c}$ & $6.00 \mathrm{~b}$ & $3.82 \mathrm{c}$ & $7.08 \mathrm{~b}$ & $119.16 \mathrm{~b}$ & $37.00 \mathrm{a}$ \\
T4 & $13.44 \mathrm{~d}$ & $6.20 \mathrm{~b}$ & $3.56 \mathrm{c}$ & $4.45 \mathrm{c}$ & $106.98 \mathrm{~b}$ & $33.42 \mathrm{~b}$ \\
T5 & $19.20 \mathrm{a}$ & $9.40 \mathrm{a}$ & $4.40 \mathrm{~b}$ & $7.10 \mathrm{~b}$ & $114.02 \mathrm{~b}$ & $35.12 \mathrm{~b}$ \\
\hline CV $(\%)$ & 7.50 & 15.70 & 10.90 & 6.20 & 9.10 & 8.70 \\
\hline
\end{tabular}

${ }^{\star} \mathrm{T} 1$ = soil (reference treatment), T2 = soil + cattle manure $(2: 1, \mathrm{v}: \mathrm{v}), \mathrm{T} 3=$ soil + earthworm humus,(2:1, v:v), T4 = soil + plant organic matter (2:1, v:v), and T5 = soil + cattle manure + earthworm humus + plant organic matter (2:1:1:1, v:v:v:v). Means followed by the same letter in the column do not differ significantly by the Scott-Knott test at $5 \%$ probability. 
Regarding the variables number of leaves and number of shoots, it was observed that the cuttings submitted to treatment 5 [soil + bovine manure + + earthworm humus + plant organic matter (2:1:1:1, v:v:v:v)] presented the best results.

Bovine manure and organic matter have physical, chemical and biological agents that act in a beneficial way in the rooting and nutrition of cuttings (Lima et al., 2013). The presence of humus, according to Furlan et al. (2007) and Pereira et al. (2010), can give the substrate an increase in the content of micronutrients, nitrogen, phosphorus, potassium and sulfur. In addition, it can improve the structure thereof, supplying and increasing the microbial activity, which may aid in the growth and renewal of leaves and shoots. So, possibly the good results verified for the variables number of leaves and number of shoots in this treatment may be related to the availability of organic matter and nutrients, as well as to the beneficial action of microorganisms.

As for the variables shoot and root length, as well as for fresh mass and dry mass of cuttings, it was verified that the best results were obtained in treatment 2 [soil + bovine manure $(2: 1, \mathrm{v}: \mathrm{v})]$. This was possibly due to the fact that the bovine manure used to formulate the substrate presented a considerable amount of potassium and other macronutrients necessary for the full development of the plants. According to Medeiros et al. (2007) and Sampaio et al. (2007), the positive effect of bovine manure on plant development is due not only to nutrient supply, but also to improved fertility and soil structure.

These results resemble those found by Amaro et al. (2013), who studied the vegetative propagation of Mentha arvensis on different substrates and observed that the variables shoot length, root length, total number of shoots and dry masses were higher when a soil + washed sand + bovine manure (2:1:1, v:v:v) mixture was used as substrate. However, divergent results were found by Paulus et al. (2011), working in a protected environment and in the field, in the state of Paraná, who verified that the substrate based on soil + + sand + bovine manure was not efficient to promote better responses for such variables in Mentha gracilis and Mentha $\mathrm{x}$ villosa, being found a higher effect when using the commercial substratum Plantmax $\AA$, based on expanded vermiculite and organic material (DDL Agroindústria, Paulínia, São Paulo).

In this way, the importance of studies on the management used in the vegetative propagation of the species and the adequate use of substrates for the production of healthy and quality seedlings is highlighted.

Regarding the variable number of shoots, weekly counts were carried out, where it was verified that the cuttings showed increasing responses over time in all the substrates used, with emphasis on treatment 5 [soil + bovine manure + earthworm humus + plant organic matter (2:1:1:1, v:v:v:v)], reaching, at the end of the experiment, a mean of 9.4 shoots per cutting, about $57 \%$ higher than the control treatment (Figure 1).

$$
\square \mathrm{T} 1=\text { Soil }
$$

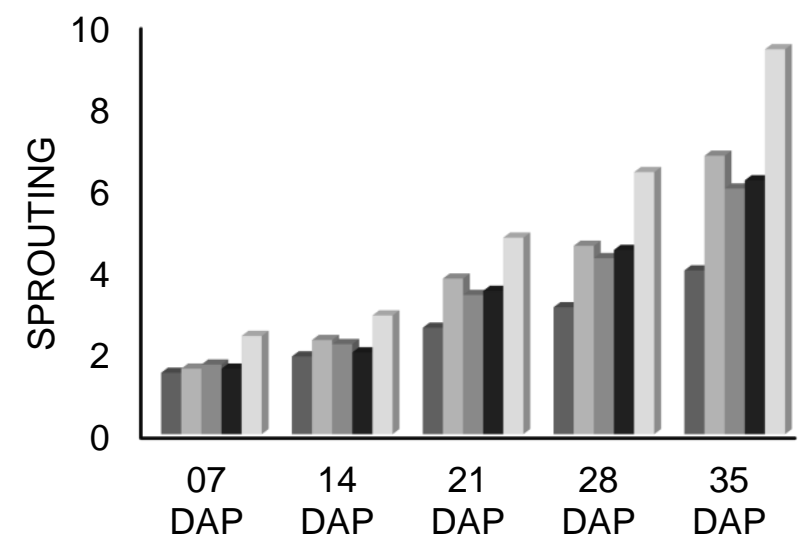

- T2 = Soil + Bovine Manure (2:1)

- T3 = Soil + Earthworm Humus (2:1)

-T4 = Soil + Plant Organic Matter

T5 = Soil + Manure + Humus +

Organic Matter (2:1:1:1)

DAP

Figure 1 - Mean values for shoots at 7, 14, 21, 28, and 35 days after planting (DAP) of cuttings of Lippia alba in different substrates, shown by treatment sequence and submitted to the Scott-Knott test at $5 \%$ probability.

According to the chemical analysis performed on the substrates, treatment 1 (soil) had the lowest amount of nutrients, therefore the failure of the control treatment in relation to the others was probably due to the low availability of nutrients for adequate rooting of the cuttings. According to Kämpf (2005), inorganic substrates, such as sand and pure soil, have low nutrient reserves, in addition to high density and low porosity, which impairs root development and consequently plant growth.

In the commercial propagation of $L$. alba, at 30 days after planting, a cutting shows at least six developed shoots and is suitable for planting (Marchese et al., 2010). The results of the present work show that the cuttings are not within the commercial standard only in the control treatment, therefore, the substrates used prove to be effective in the production of seedlings of this species. 
From the practical and economic point of view, the use of treatment 2 (soil + bovine manure) is a more viable alternative, since it presents satisfactory results in the production of lemon balm seedlings and has a lower cost.

\section{Conclusions}

The substrates that presented the best responses were soil + bovine manure $(2: 1, v: v)$ and soil + bovine manure + earthworm humus + plant organic matter (2:1:1:1, v:v:v:v), being indicated for the production of Lippia alba seedlings by cutting.

The substrate soil + bovine manure is the most economically viable for producers.

\section{References}

Aguiar JS, Costa MC, Nascimento SC, Sena KX (2008) Antimicrobial activity of Lippia alba (Mill.) NE Brown (Verbenaceae). Revista Brasileira de Farmacognosia 18(3):436-440.

Alt D, Peters I (1993) Analysis of macro and trace elements in horticultural substrates by means of the $\mathrm{CaCl}_{2} / \mathrm{DTPA}$ (CAT) method. Acta Horticulturae 342(1):287-292.

Amaro HTR, Silveira JR, David ADS, Resende MAV, Andrade JAS (2013) Tipos de estacas e substratos na propagação vegetativa da menta (Mentha arvensis L.). Revista Brasileira de Plantas Medicinais 15(3):313-318.

Coelho MFB, Spiller C, Azevedo RAB, Camili, EC (2016) Substrates and types of cuttings of Lippia alba (Mill) N. E. Brown. International Journal of Current Multidisciplinary Studies 5(5):868-870.

Costa AMG, Costa JTA, Junior ATC, Correia D, Medeiros Filho S (2008) Influência de diferentes combinações de substratos na formação de porta-enxertos de gravioleira (Annona muricata L.). Revista Ciência Agronômica 36(3):299-305.

Freire MFI (2004) Plantas medicinais: a importância do saber cultivar. Revista Científica Eletrônica Agronomia, ano III 5(1):1-9.

Furlan F, Costa MMSS, Costa MLA, Marini D, Castoldi G, Souza JH, Pivetta LA, Pivetta LG (2007) Substratos alternativos para produção de mudas de couve folha em sistema orgânico. Revista Brasileira de Agroecologia 2(2):1686-1689.

Garcés PMI, Araque JFC, Prieto DA, Stashenko E (2010) Morfología, anatomía, ontogenia y composición química de metabolitos secundarios en inflorescencias de Lippia alba (Verbenaceae). Revista de Biología Tropical 58(4):1533-1548.
Hennebelle T, Sahpaz S, Joseph H, Bailleul F (2008) Ethnopharmacology of Lippia alba. Journal of ethnopharmacology 116(2):211-222.

Kämpf AN (2005) Produção comercial de plantas ornamentais. Guaíba: Agrolivros. 2: 254p.

Köppen WP (1923) Die Klimate der Erde: Grundriss der Klimakunde. Walter de Gruyter \& Company. 369p.

Lacerda MRB, Passos MA, Rodrigues JJV, Barreto LP (2006) Physical and chemical characteristics of coir dust and sisal residue for seedling production of sabiá (Mimosa casalpiniaefolia Benth). Revista Árvore 30(2):163-170.

Lima CB, Boaventura AC, Jorge AP (2013) Substratos, recipientes e concentrações de fertilizante orgânico na estaquia de Lippia alba (Mill.), Ocimum gratissimum L. e Mikania laevigata Sch. Bip. Científica 41(2):199-208.

Marchese JA, Pissaia E, Bocchese VC, Cambruzzi E, Colussi G, Hart V, Magiero EC (2010) Estacas de diferentes diâmetros na propagação de Lippia alba (Mill.) NE Br.-Verbenaceae. Revista Brasileira de Plantas Medicinais 12(4):506-509.

Medeiros DC, Lima BAB, Barbosa MR, Anjos RSB, Borges RD, Cavalcante Neto JG, Marques LF (2007) Produção de mudas de alface com biofertilizantes e substratos. Horticultura Brasileira 25(3):433-436.

Melo LCA, Silva CA, Dias BO (2008) Caracterização da matriz orgânica de resíduos de origens diversificadas. Revista Brasileira de Ciência do Solo 32(1):101-110 .

Neves TS, Carpanezzi AA, Zuffellato-Ribas KC, Marenco, RA (2006) Enraizamento de corticeira-daserra em função do tipo de estaca e variações sazonais. Pesquisa Agropecuária Brasileira 41(12):16991705.

Paulus D, Valmorbida R, Toffoli E, Paulus E, Garlet T (2011) Avaliação de substratos orgânicos na produção de mudas de hortelã (Mentha gracilis R. Br. e Mentha $x$ villosa Huds.). Revista Brasileira de Plantas Medicinais 13(1):90-97.

Pereira PC, Melo B, Freitas RS, Tomaz MA, Freitas CDJP (2010) Mudas de tamarindeiro produzidas em diferentes níveis de matéria orgânica adicionada ao substrato. Revista Verde de Agroecologia e Desenvolvimento Sustentável 5(3):152-159.

Pinto FA, Franco ETH (2009) Propagação Vegetativa de Lippia alba (Mill.) N. E. Brown (Verbenaceae). Caderno de Pesquisa Série Biologia 21(2):61-75. 
Sampaio EVSB, Oliveira NMB, Nascimento PRF (2007) Eficiência da adubação orgânica com esterco bovino e com Egeria densa. Revista Brasileira de Ciência do Solo 31(5):995-1002.

Silva FM, Motta SI, Padovan MP, Carneiro LF, Nascimento JS, Colombo LR (2012) Avaliação de substratos à base de húmus de minhoca e casca de arroz carbonizada para produção de mudas de mamoeiro. Cadernos de Agroecologia 7(2):1-5.
Silva GC, Oliveira LM, Lucchese AM, Silva TR, Nascimento MN (2015) Vegetative propagation and early growth of Lippia origanoides (alecrim-de-tabuleiro). Horticultura Brasileira 33(2):236-240.

Yamamoto PY, Colombo CA, Azevedo Filho JA, Lourenção AL, Marques MOM, Morais GDDS, Chiorato AF, Martins ALM, Siqueira WJ (2008) Performance of ginger grass (Lippia alba) for traits related to the production of essential oil. Scientia Agricola 65(5):481-489. 